\title{
Transcription Factor AP-2-Epsilon
}

National Cancer Institute

\section{Source}

National Cancer Institute. Transcription Factor AP-2-Epsilon. NCI Thesaurus. Code C117148.

Transcription factor AP-2-epsilon (442 aa, $46 \mathrm{kDa}$ ) is encoded by the human TFAP2E gene. This protein plays a role in the regulation of gene transcription. 